\title{
KÜLÖNBÖZŐ KOMMUTÁTOR ÜLÉK-KIALAKÍTÁSOK EGYSÉGESÍTÉSÉNEK FOLYAMATA
}

\author{
Pleszkó István \\ MSc hallgató, Miskolci Egyetem, Gyártástudományi Intézet \\ 3515 Miskolc, Miskolc-Egyetemváros, e-mail: pleszkoistvan84@gmail.com \\ Gergely Krisztián \\ minöségbiztositási mérnök motorgyártási területen, Robert Bosch Power Tool Kft. \\ 3526 Miskolc, Robert Bosch park 1, e-mail: krisztian.gergely@hu.bosch.com \\ Varga Gyula \\ egyetemi docens, Miskolci Egyetem, Gyártástudományi Intézet \\ 3515 Miskolc, Miskolc-Egyetemváros, e-mail: gyulavarga@uni-miskolc.hu
}

\begin{abstract}
Absztrakt
A Miskolci Egyetem Gyártástudományi Intézete és a miskolci Robert Bosch Power Tool Kft. motorgyártás minőségbiztositásért felelös csoportjának közös munkája részeként megvizsgáltuk a kéziszerszámok motorjaiban alkalmazott kommutátor ülékeket, a vállalat részéröl felmerülö problémára a cégen belül alkalmazott módszerek segitségével kerestük a megoldást. A tanulmányban bemutatásra kerülnek a korszerü minöségbiztositási módszerek alkalmazásai, úgymint a Pareto-elemzés, ok-okozati elemzés, 5Why módszer, továbbá az ezen módszerek segitségével feltárt gyökérok tesztjei.
\end{abstract}

Kulcsszavak: minöségbiztositás, motorgyártás, kommutátor

\begin{abstract}
As part of the joint work of the Institute of Manufacturing Science at University of Miskolc and the quality assurance group of Robert Bosch Power Tool Ltd. we examined commutator seats used in power tool motors. We used inner problem-solving methods to the company's problem. This study introduces the application of modern quality assurance methods, such as Pareto-analysis, Cause and Effect Analysis, 5Why, furthermore the tests of the root cause discovered by these methods.
\end{abstract}

Keywords: quality assurance, engine production, commutator

\section{Bevezetés}

E tanulmányban egy több évet átfogó motor gyártással kapcsolatos folyamat egy része kerül bemutatásra, mely során a feladat a gyártásban lévő kommutátor ülék-kialakítások vizsgálata. A vizsgálat az előzetesen megvalósított teszteket is bemutatja. Ismertetésre kerülnek a Bosch által alkalmazott problémamegoldási módszer lépései. Ennek részeként az összegyüjtött adatok alapján Pareto-elemzést végeztünk. A vizsgálat által feltárt leggyakoribb hiba okai meghatározása céljából elkészítettünk egy Ishikawa-diagramot, majd kiválasztottuk közülük a legvalószínübbet. A kiválasztott hibaok gyökérokának meghatározásához a 5 Why módszert használtuk, melynek ismeretében további teszteléseket végeztünk. Az elvégzett élettartam vizsgálatok, préselési erőket vizsgáló tesztek és a 
végeselemes szoftverrel lefuttatott szimulációk eredményeinek ismeretében javaslatot adtunk az ülék módosítására.

\section{Kommutátor ülékek}

Mielőtt a tesztek kiértékelésére térnénk, érdemes tisztázni, hogy a miskolci Robert Bosch Power Tool Kft.-nél milyen ülék típusok használatosak, azok milyen szerszámgépekben kerülnek alkalmazásra, és hogy mik voltak az ülékek egységesítésének okai.

Az úgynevezett B-ülékek (1. ábra) a hobbi felhasználásra szánt, zöld színủ szerszámokban kerülnek alkalmazásra. A B-ülékek maximum 9,65 mm átméröjüek, körben tizenkét fog helyezkedik el rajtuk 30 fokonként. A fogak magassága $0,25 \mathrm{~mm}$, szélességük $0,5 \mathrm{~mm}$.

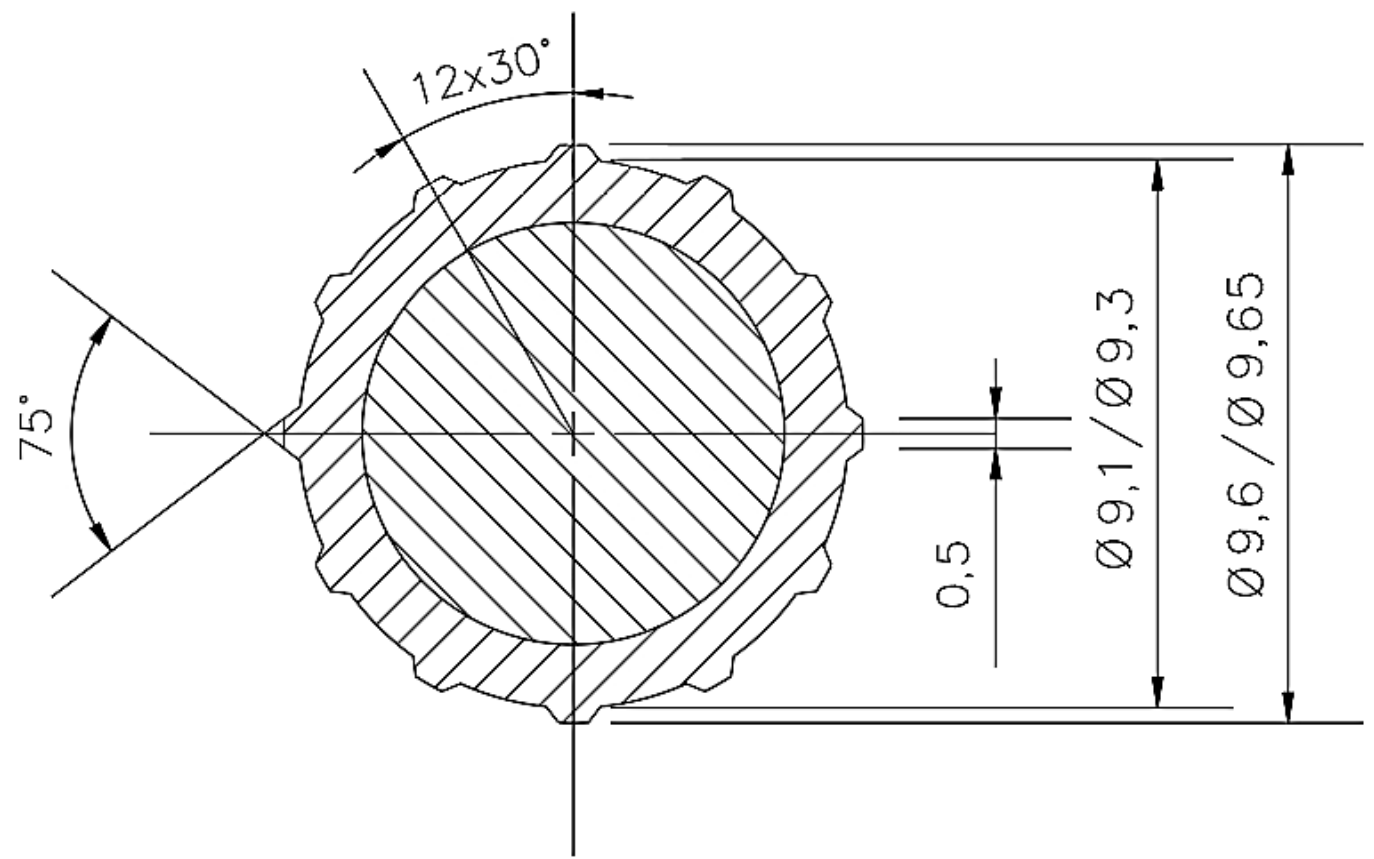

1. ábra. A B-ülék geometriai jellemzői

A D-ülékeket (2. ábra) az ipari felhasználásra szánt szerszámgépekben alkalmazzák. Ezen ülékek kialakítása jóval robusztusabb, a fogak szélessége a duplája a B-ülékekének, emiatt közelebb helyezkednek el egymáshoz. Az átmérőjük egyforma, a fogak száma és elhelyezésük szöge sem tér el a „B” kialakításúakétól.

A B-ülékről D-re váltás előnyei a hobbi felhasználási célú gépeknél a következők:

- A B-ülékek legnagyobb hátránya, hogy a kommutátor rögzítése a gyártás során nem elegendő. A kommutátor préselést követő lépések közben akár $0,1 \mathrm{~mm}$-rel elmozdulhatnak a vasmag irányába, ezáltal előfordulhat olyan eset, hogy türésen belülre préselt kommutátor a gyártás végeztével kicsúszik a rajzi türésből. Ezzel szemben a D-ülékek alkalmazásánál a kommutátorok a helyükön maradnak, vagyis ennek az üléktípusnak a használata nagyban megkönnyíti és biztonságossá teszi a kommutátor préselési méret rajzi méreteken belül tartását. 
- Továbbá idő- és költségcsökkenés várható a kommutátorok, a gyártás közben emberi hibából adódó újra felhasználása esetén. Ugyanis újra felhasználás esetén a B-ülékekre másodszor rögzíteni már csak ragasztással lehet, aminek komoly idő- és költségbeli vonzatai vannak. A D típusú ülékek ezzel szemben, kialakításuknak köszönhetően könnyedén kibírnak egy másodszori felpréselési folyamatot is.

- A D-ülékek bevezetésével csökkenhet a gyártás közbeni esztergálás alatt tapasztalható lamella ütés, stabilabban ülhetnek a kommutátorok a helyükön.

- Végül, de nem utolsósorban az is a váltás mellett szól, hogy megnőhet a szerszámgépek motorjainak élettartama.

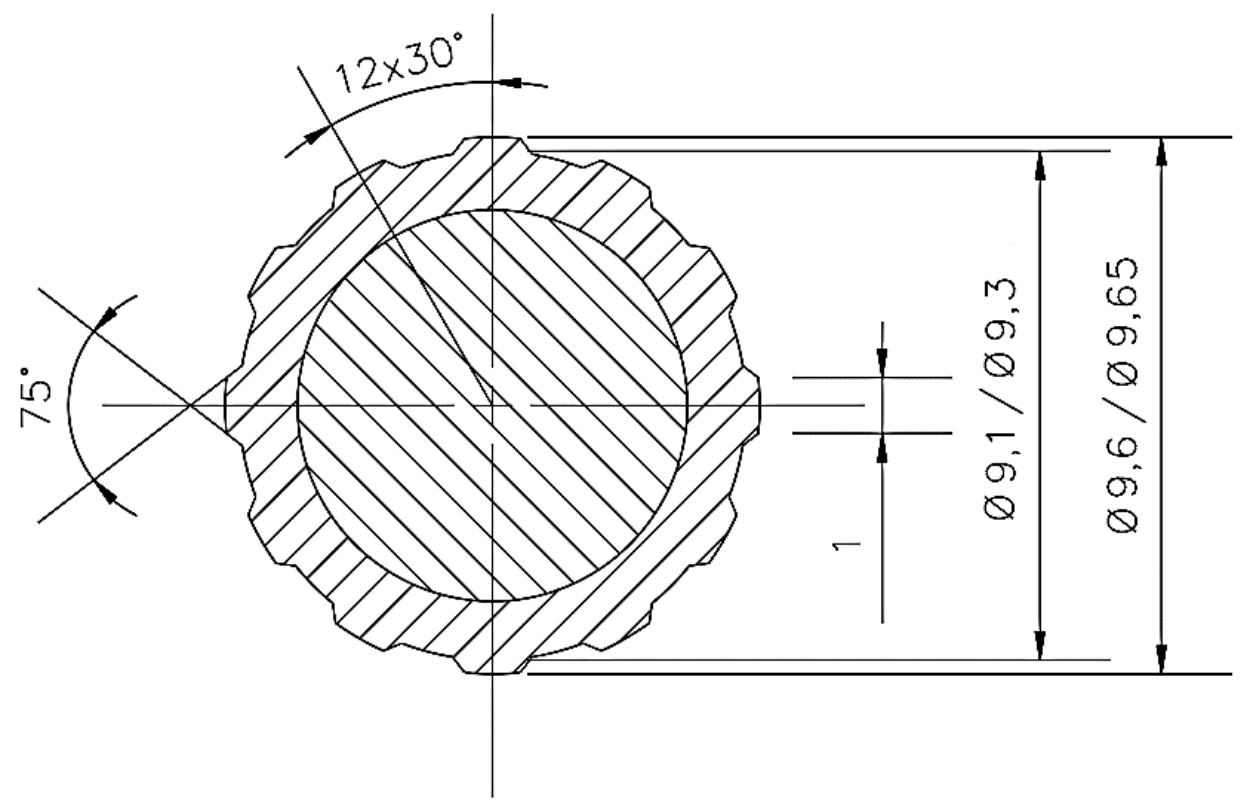

2. ábra. A D-ülék geometriai jellemzöi

\section{Az alkalmazott problémamegoldási folyamat}

Ezen okok elegendőek ahhoz, hogy a „B” kialakítású üléktípust megszüntessük, a hobbi felhasználásra szánt szerszámgépekben is a D-ülékek kerüljenek alkalmazásra. E törekvést célzó tesztek nagy számban megvalósításra kerültek, viszont azok összegzéséből megállapítható, hogy nem eredményezték az elvárt eredményt. A kísérletek mindössze 50\%-a volt sikeres kimenetelü. Emiatt a D-ülékek nem vezethetők be a hobbi felhasználásra szánt szerszámgépek gyártásába, a hiba kiváltó okának megtalálásához további elemzések elvégzésére volt szükség.

Az elemzések módszertana több minőség ellenőrzéssel, minőségbiztosítással kapcsolatos szakkönyvben, tankönyvben megtalálható [1-4]. Ezek tartalmazzák a Pareto- és az Ishikawa elemzések lépéseit is. Az első lépés az adatok összegyưjjtése, melyek birtokában el lehet kezdeni azok valamilyen kiválasztott szempont szerinti kategorizálását és sorba rendezését, majd a Pareto-diagram megrajzolását [4]. 
A lefuttatott teszteket összegezve az 1. táblázatban felsorolt hibatípusok és gyakoriságok kerültek beazonosításra:

1. táblázat. Az elöforduló hibák és relatív gyakoriságuk

\begin{tabular}{|l|r|}
\hline Hibatípus & Relatív gyakoriság \\
\hline kommutátor sérült & $50,36 \%$ \\
\hline szénkefe tartó sérült & $24,82 \%$ \\
\hline szénkefe sérült & $13,87 \%$ \\
\hline gyanta repedt & $3,65 \%$ \\
\hline fogaskerék sérült & $2,92 \%$ \\
\hline motor sérült & $2,92 \%$ \\
\hline irányváltó kapcsoló sérült & $0,73 \%$ \\
\hline állórész sérült & $0,73 \%$ \\
\hline
\end{tabular}

Ahogy az 1. táblázatból is látszik, a legtöbbször előforduló hiba a kommutátor és a szénkefe tartó sérülése. A szénkefe sérülésének relatív gyakorisága is $10 \%$ felett van. A többi hiba előfordulása e háromhoz képest nem számottevő.

A Pareto-elemzés eredményét a 3. ábrán látható Pareto-diagramban szemléltettük.

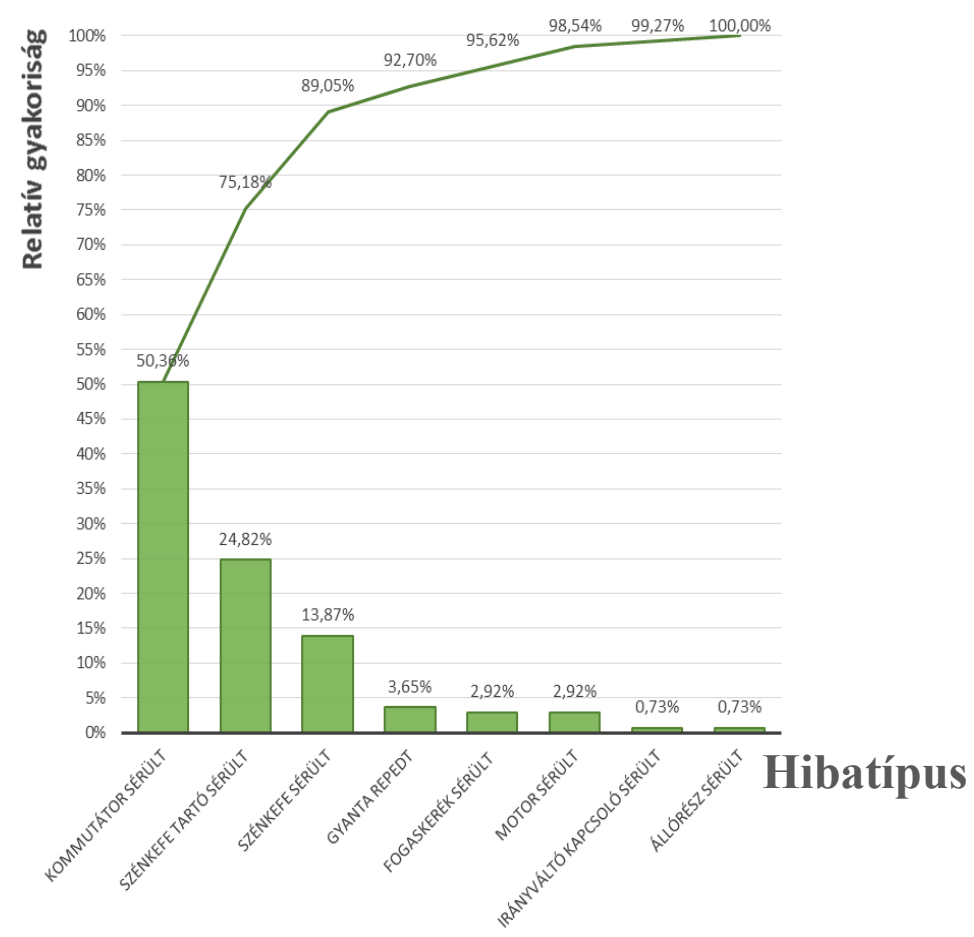

3. ábra. Az ülékváltással kapcsolatban elöforduló hibák Pareto-diagramja 
A leggyakoribb hibának a kommutátor sérülése bizonyult. Ezért erre a hibatípusra kell megalkotni az Ishikawa-diagramot (4. ábra) [4-5].

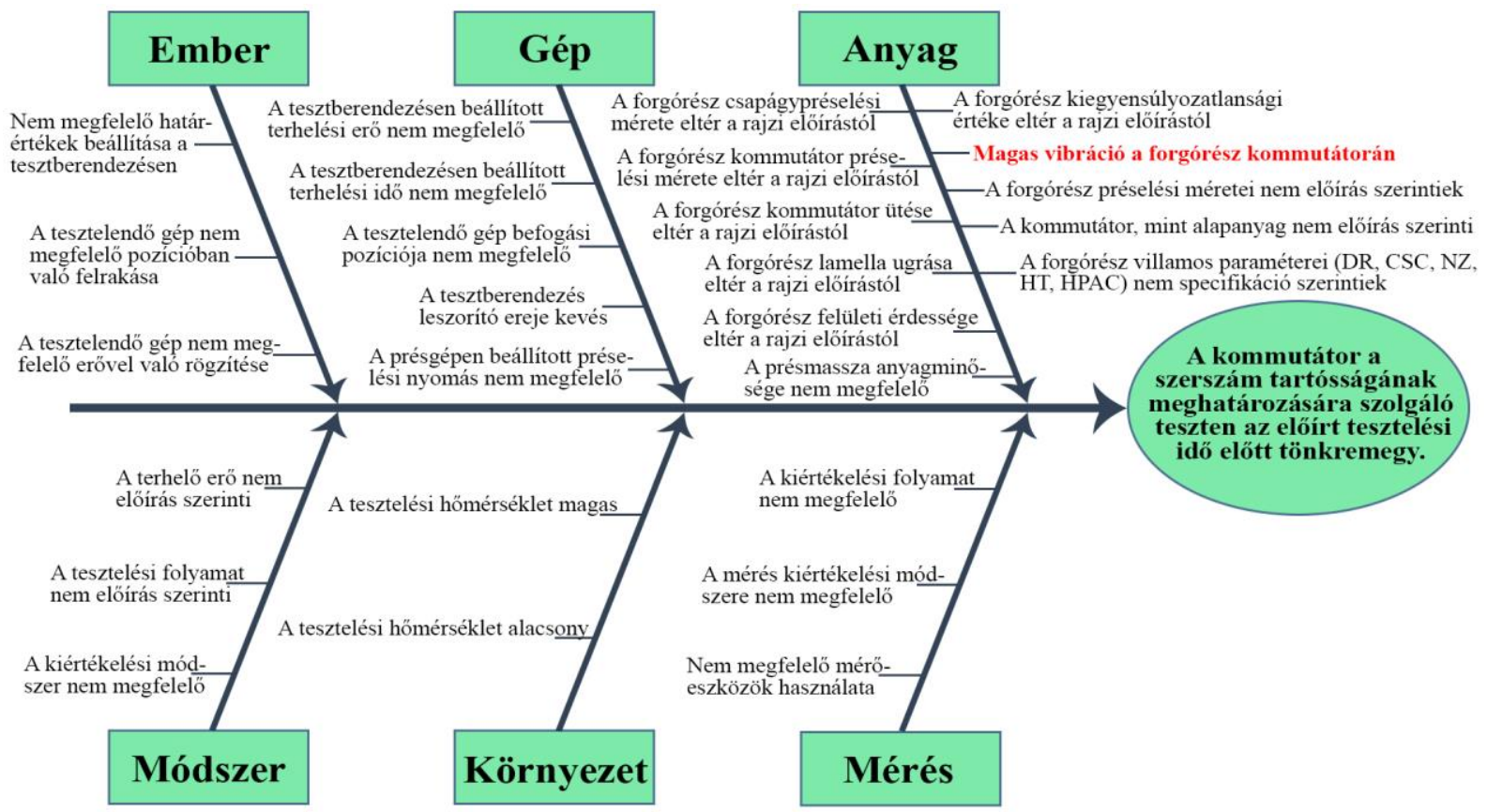

4. ábra. A kommutátor sérülés bekövetkezését vizsgáló Ishikawa-diagram

A fentebb felsorolt hibalehetőségek közül a magas vibráció a többivel ellentétben nincs ellenőrizve a gyártás során, így ez jelölhető meg a legvalószínübb hibaokként. A 5Why módszerrel [6] lehet megkeresni a gyökérokát:

1. Miért: Magas a vibráció a forgórész kommutátorán.

2. Miért: A teszt alatt a kommutátor nem megengedhető mértékben rezeg.

3. Miért: A tesztelés alatt álló gép leterhelt kihajtótengelyéről a vibráció a forgórész tengelyen keresztül áttevődik a kommutátorra.

4. Miért: A forgórész üléke és a kommutátor belső átméröje között az átfedés mértéke túl nagy.

5. Miért: Az ülék bordaszélessége túl nagy.

\section{A probléma gyökérokának tesztelése}

\section{1. Élettartam tesztek elvégzése}

Az ülék bordaszélességének teszteléséhez a szerszámgépek az alapján kerültek kiválasztásra, hogy melyek előzetes tesztelésénél adódtak problémák a legnagyobb számban. A D-ülékkel szerelt forgórészek esetében a tesztek sikertelenek voltak. Összehasonlításképpen a tesztek elkészültek az eredeti, Bülékekkel is, egyik esetben sem volt tapasztalható semmilyen meghibásodás. 


\subsection{Préselési erők vizsgálata}

A B- és D-ülékek közötti eltérések a felsajtoló erőknél is tapasztalhatók. A kommutátor B-ülékre való felhelyezéséhez általában 1000-1150N erő kell, míg a D-ülékre való felpréseléshez a négyszerese, azaz körülbelül 4000-4600N (5. ábra).
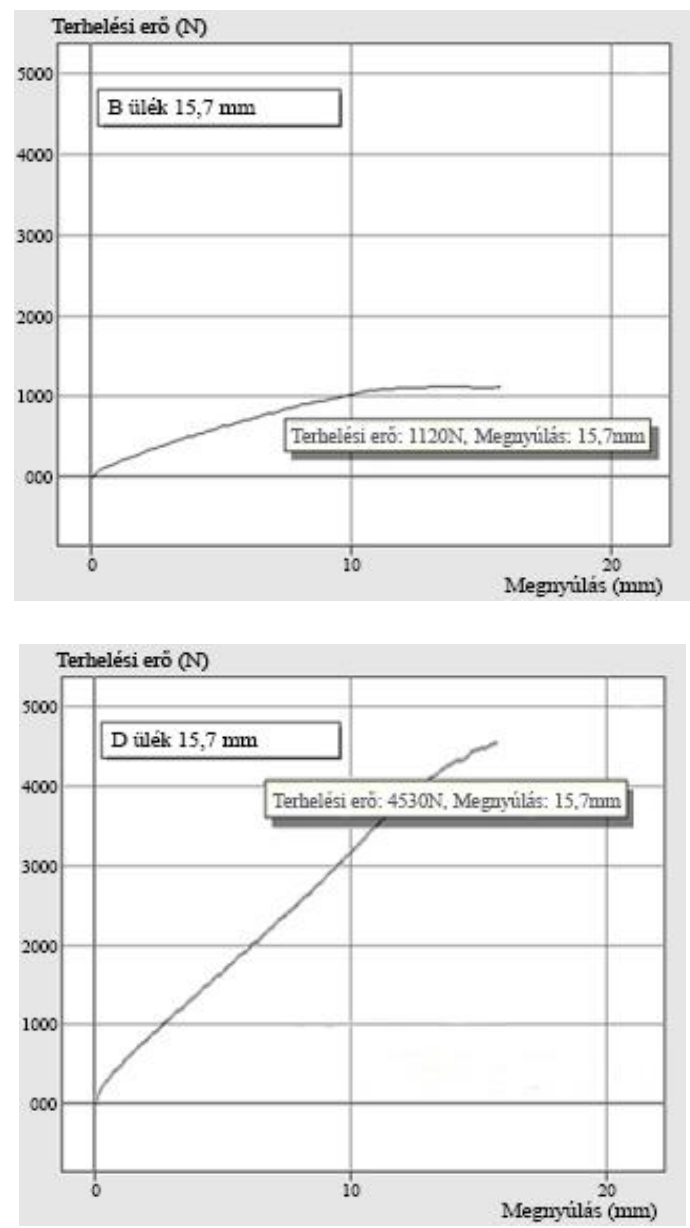

5. ábra. A B-, és D-ülék felpréseléséhez szükséges erök

\subsection{Tesztek elvégzése végeselemes szoftverrel}

A két üléktípus közötti különbségek az Abaqus nevü végeselemes szoftverrel készült szimulációk alapján is bizonyíthatók. A végeselem rendszerek müködésének alapjairól információ nyerhető pl. az [7-8] irodalomból. Ennél a tesztnél mutatkozik a legszemléletesebb módon a probléma forrása. Az Abaqus programban létrehozott kommutátor ülékek (B- és D ülék) modelljén lefuttatott szimulációban (1) a forgórész tengelye, (2) a kommutátor ülék és (3) a kommutátor között ébredő von Mises feszültségek jelennek meg (6. ábra) [9]. 

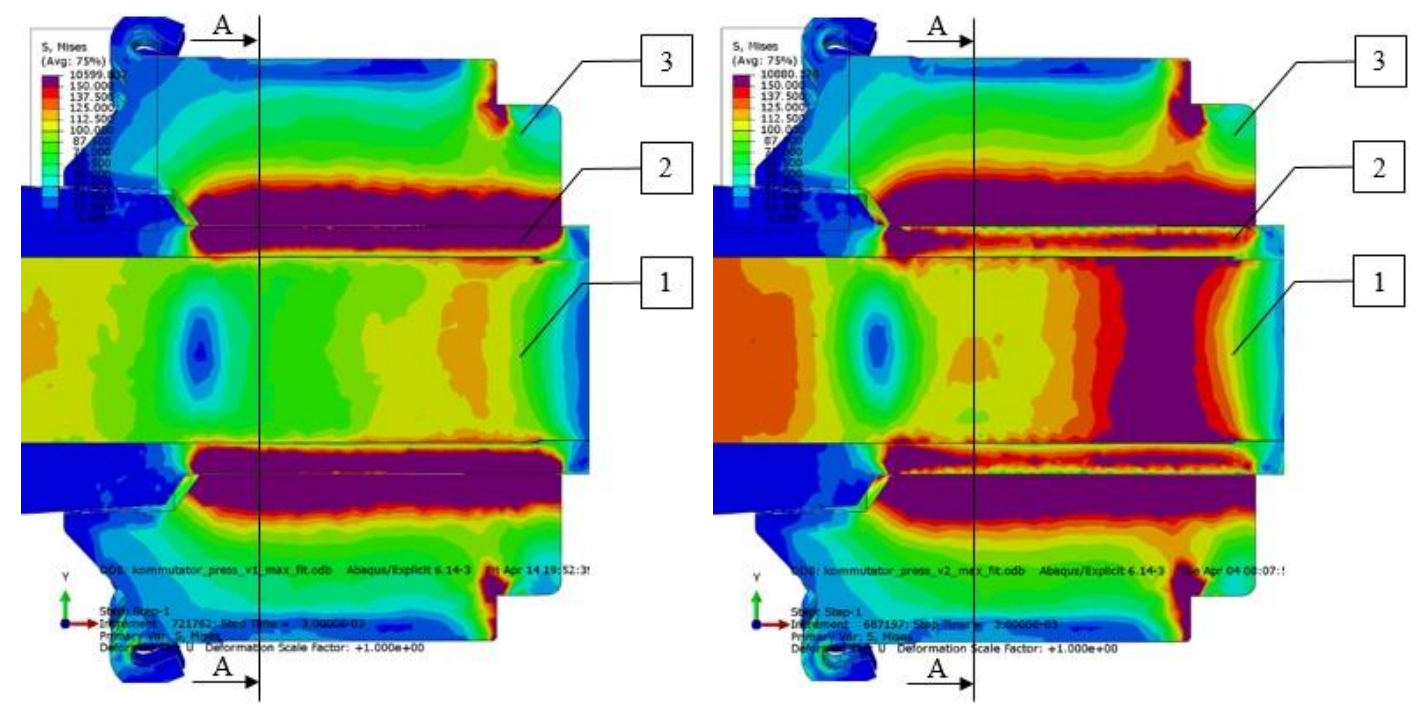

6. ábra. A B-, és D-ülék esetében keletkezö feszültségek oldalnézetböl

A 6. ábrán is látható módon, a B-ülék esetében az ébredő feszültség nagy része a kommutátor ülékben koncentrálódik, így nem sérül maga a kommutátor. A D-üléknél ezzel szemben a feszültség a tengelybe és a kommutátorba is áttevődik, ezzel vibrációt kelt és a kommutátor tönkremenetelét okozza.
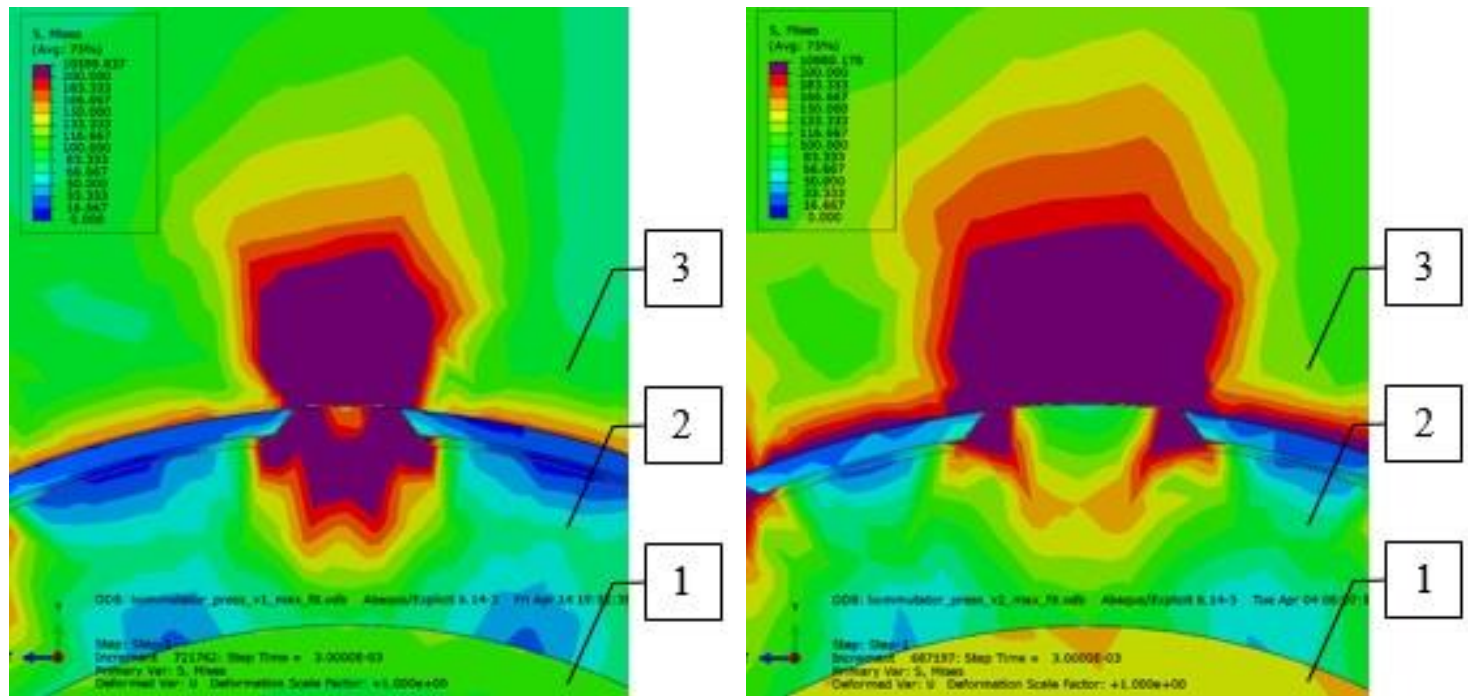

7. ábra. A B-, és D-ülék esetében keletkezö feszültségek az A-A metszetben

A 7. ábrán a B- és D-ülékek A-A metszetbeli pillanatképei láthatók. Itt is megfigyelhető, hogy a Bülék esetén a keletkező feszültségek nagy része a kommutátor ülékben koncentrálódik. Összehasonlításképpen a D-ülék esetében a kommutátor ülék egy kis részében, a széleinél figyelhető meg csupán generált feszültség. A teljes feszültség nagy része a kommutátorban összpontosul. 


\section{5. Összefoglalás}

A préselési erők vizsgálatából kiderül, hogy a D-ülékek rögzítéséhez négyszer akkora erő kell, mint a B-ülékekhez. Ez a bordák szélességével van összefüggésben és mivel a D-ülékeken a bordák szélesebbek, ez azt is jelenti, hogy müködés során nagyobb feszültséget visznek át a kommutátorokba, ami a tesztek felének bukásához vezethet. A szimulációs program alapján is megállapítható, hogy a B-ülék esetében a kommutátorban ébredő feszültséget az alkatrész még képes elviselni müködés közben, a Dülékkel ellátott szerszámgépek esetén viszont a feszültségek már túl nagyok a sérülésmentes müködés fenntartásához. Élettartam vizsgálat esetén ez okozza a termék tönkremenetelét.

A tesztek végkimenetelét tekintve a D-ülék sorozatgyártásban való használatát nem lehet elkezdeni. Egy új üléktípus bevezetése javasolt, aminek bordaszélessége a B- és a D-ülék között van.

\section{Köszönetnyilvánítás}

A cikkben ismertetett kutató munka az EFOP-3.6.1-16-2016-00011 jelü „Fiatalodó és Megújuló Egyetem - Innovatív Tudásváros - a Miskolci Egyetem intelligens szakosodást szolgáló intézményi fejlesztése" projekt részeként - a Széchenyi 2020 keretében - az Európai Unió támogatásával, az Európai Szociális Alap társfinanszírozásával valósul meg.

\section{Irodalom}

[1] M. O. Lorenz: Methods of measuring the concentration of wealth. Publications of the American Statistical Association 1905, 9(70):209-219. https://doi.org/10.2307/2276207

[2] Róth András (szerk.): Minőségbiztosítás és irányítás az ISO 9000 alapján. Aktuális gyakorlati tanácsadó minőségbiztosítási és müszaki szakembereknek, 13. rész: Minőségbiztosítási módszerek és eszközök. VERLAG DASHÖFER Gazdasági és Jogi szakkiadó kft, Budapest, 1998.

[3] Koczor Zoltán (szerk.): Bevezetés a minőségügybe (A minőségügy gyakorlati kérdései), Müszaki Könyvkiadó, Budapest, 1999.

[4] Bedzsula Bálint, Erdei János, Dr. Topár József, Dr. Tóth Zsuzsanna Eszter: Minőségmenedzsment, Oktatási segédanyag a Müszaki menedzser és a Vezetés és szervezés mesterszakos hallgatók számára, Budapesti Müszaki és Gazdaságtudományi Egyetem, Budapest, 2015

[5] Dr. Tolvaj Béláné: Segédlet, „Komplex tervezés” feladatok kidolgozásához (Gépészmérnöki szak, Minőségbiztosítási szakirány), Miskolci Egyetem, Miskolc, 2001

[6] Koncz Annamária: A 8D problémamegoldó technika, Repüléstudományi közlemények, Vol.: 3, 2015, pp.: 7-17, http://www.repulestudomany.hu/folyoirat/2015_3/2015-3-01-0227_Koncz_Annamaria.pdf (megtekintés dátuma: 2019.08.12.)

[7] Páczelt István, Szabó Tamás, Baksa Attila: A végeselem-módszer alapjai, A HEFOP 3.3.1-P.2004-09-0102/1.0 pályázat támogatásával készült jegyzet, 2007

http://www.mech.uni-miskolc.hu/ paczelt/notes/VEM-ME-jegyzet.pdf (megtekintés dátuma: 2019.08.12.)

[8] http://moodle.autolab.uni-pannon.hu/Mecha_tananyag/vegeselem_modszerek/ch02.html (megtekintés dátuma: 2019.08.12.)

[9] https://www.simscale.com/docs/content/simwiki/fea/what-is-von-mises-stress.html, (megtekintés dátuma: 2019.08.12.) 